\title{
Feminism as seen in juana, the secondary character of john steinbeck's the pearl
}

\author{
Heribertus Binawan ${ }^{1 *}$ \\ ${ }^{1}$ Universitas Mercu Buana Yogyakarta, Yogyakarta, Indonesia \\ ${ }^{1}$ binawan@mercubuana-yogya.ac.id \\ * corresponding author
}

\section{ARTICLE INFO}

Article history

Received April 07, 2019

Revised April 28, 2019

Accepted May 18, 2019

Keywords

feminism

woman struggle

sociocultural

\section{ABSTRACT}

This study is intended to find out feminism in Juana, the secondary character of Steinbeck's "The Pearl". There are two problems that became the basis questions: (1) how is Juana characterized? (2) how is feminism revealed in Juana? To obtain the answers to the two questions above, a library study was carried out. It is done by studying the information and sources which were picked from referential books and studies of Steinbeck's work. Sociocultural approach is applied to analyze the story, since the problems have close relationship with people and their ideas of feminism. Social, cultural, and historical background is the factors that people's characteristics and build the ideas of feminism. Based on the result of analysis of the story, there are four points that can be concluded. First, the study on The Pearl has shown that Juana represents woman's struggles in the family. Second, there is a contrast between Kino and Juana. In contrast to the savage and brutal Kino, Juana retains the human qualities. Third, Juana's feminism can be seen through her bravery to speak her idea about the pearl. Fourth, Juana's feminism has made the story of The Pearl becomes full of conflicts.

\section{Introduction}

Some people say that women are inherently inferior to men. Men are smarter and stronger than women. Women are more emotional and delicate. Women exist for the benefit of men. Sometimes, in daily life, a man may force a woman to go with his principle as long as he has a very good reason for making his demand. These facts are also exposed in the literary works, The Pearl by John Steinbeck.

This novel is not very popular and this could be one of the reasons why not so many scholars are interested to discuss about it. It depicts clearly about a mixed blood family life that earns their living from the ocean as a pearl diver. This Mexican-Indian family lives harmoniously in a particular village in Mexico until one day Kino, the husband, found a pearl that becomes the source of long and tiring conflicts within the family.

This is one particular thing that differentiates The Pearl from others Steinbeck's novel. of The Pearl is quite flowing simple and honest. The characters are also described so clearly. the tradition of naturalism, Steinbeck depicts his characters thoroughly, and they are portrayed in such way that we shall get an idea what kind of people they are and not only how they look (Omrany, Maryam and Pishkar, Kian).

In the novel, Juana's position is weak. Kino as a man always insists his wife to go on his way, even sometimes it is contrary to her own belief. Kino as a man sees Juana as an inferior creature. The fact shows the truth that Juana as a woman has strength to survive even though her husband attacks her. 
Through this study, Steinbeck describes the feminism through Kino's wife. Juana as the secondary character appears to be the only symbol of woman struggle to save their beloved son instead of busy protecting the pearl. By reading and understanding the story, the readers will be able to figure out the messages the writer tries to present his work. For teaching English as a foreign language, gender and feminism can be used as lenses due to the increased presence of women in the academy (Hart).

This study has two aims to be achieved; first is to find out the character of Juana and second is to find out feminism through Juana. As we know that Juana is the only representation of a feminine character in the story but she has very important role in the story. She has a big influence in how the story is going in the middle of patriarchy society in Mexico. So, the analysis of feminism as seen in Juana is to answer each of the following questions; (1) How is Juana characterized by Steinbeck in the story? (2) How is feminism revealed in Juana?

There are five critical approaches than can be implemented in analyzing a work of literature. These five critical approaches are formalist approach, biographical approach, sociocultural-historical approach, mythopoeic approach and psychological approach (Rorberger, Mary \& Wood, Samuel H Jr.)

\section{Method}

This study applied the sociocultural-historical approach which is considered as the suitable one to analyze the feminism in the novel. The socio-cultural research goes beyond traditional academic practices and disciplines. It creates links between culture and cognition with the help of situational and contextual activities, events and tasks. Examining and observing a student as an individual being separated from the culture and community would be like missing the most important pages of his/ her life (Panhwar, Abdul Hameed \& Ansari, S).

Socio-cultural theory helps the students and teachers to develop language pedagogies. Critical analysis of the literature on the socio-cultural theory suggests that the theory has potential for forming new context-oriented language teaching-learning pedagogies which can help teachers in maximizing the effectiveness of their teaching and their student's learning. The review further suggests that the language pedagogies and activities developed from the sociocultural theory of Vygotsky may not only improve students' language skills, but it also has potential to develop students' cognition (Panhwar, Abdul Hameed \& Ansari, S).

Feminism appears since women are being assumed as a lower class than men. Politics, social, and economics are some areas where women have been defined as inferior men. Those facts make the feminist seek equal rights for women and to give them equal status to men. They want equal opportunities to complete with men.

In feminism, there are some major identifications; two of them are liberal and radical. Liberal feminism, as its name suggests, finds its roots in liberalism. Individual autonomy and the right to self-determination are primary values, and the burden is on the individual to redress inequity. Radical feminism portrays alternate worlds outside of patriarchy. Through grassroots mobilization, radical feminists create "woman space," separatist enclaves to raise awareness about the oppression of patriarchy. This "consciousness raising" is a fundamental strategy for this strand of feminists; for, without understanding, one lives with false consciousness and cannot adequately question the dominant oppressive culture.

In spite of implicit feminism over the entire story, Steinbeck is emerged feminine characteristics only through Juana's character. She is Kino's wife. As a wife, Juana serves as the lone voice of reason, continuing to warn Kino of the disastrous consequences of the pearl. As his paranoia and impulses more and more consume Kino, it is Juana who remains a realistic appraisal of the effects of the pearl.

Steinbeck as an author is hard to categorize. He has both been associated with socialism, and he has been advisor to an American president. For a story that so easily can be placed in time and space, the story is very detached from the real world. Steinbeck starts his story by giving a lively description of the environment. Then what we could see in a still webcam. The clear depiction fits well with Steinbeck's naturalistic heritage as environmental depiction was an integral part of the 
literary genre. Further, the reality during the depression years was that many people dreamt about something of their own, but few could realize their dreams. (Omrany, Maryam and Pishkar, Kian)

\section{Findings and discussion}

It is not easy to get to know the characters in The Pearl in the same way we might get to know the characters in other novels. It seems to be relative few situations. The characters are more like symbols for ideas than real people are (Davis). The Pearl, the book was published in 1966, by Heinemann Educational Book Ltd, London. The novelette consists of 86 pages.

In order to find out Juana's characters is described in the story and which parts have close relation to the other problem formulation stated in this study, summary and some points that will be discussed were made. Some sentences in the short story are underlined as the guidelines for the analysis.

The next step is analyzing the character of Juana. Here, a list of Juana's character found in the story is made. Some books concerning characters and characterization were read and referred to help understanding Juana's characters. It was concluded that this step could be used to answer the first problem.

To answer the second problem, notes on some parts that explicitly or implicitly told about Juana's feminism were taken. Next, some theories were adopted to support the analysis. This step could be used to answer the last problem in this study. Since the sociocultural-historical is adapted in this study, it is also important to analyze the main characters in the story.

Steinbeck has often been criticized for failing to create more complex and realistic characters. On the other hand, some readers find Steinbeck's purpose, especially the social criticism is best served by characterizations that clearly represent a social group or an idea (Davis).

\section{The Main Character}

It is necessary to understand the character and characterization. They are applied because the problem formulation deals with the description of the major characters. Theories of character and characterization are applied in this study. One of the theories is stated by Murphy who presents nine ways to make characters understandable and come alive (Murphy). There are personal descriptions, characters seen by another, speech, past life, conversation, reaction, direct comment, thoughts, and mannerisms.

On the other hand, Barnet, Berman and Burto present four important factors that are significantly considered in seeing the character; they are what character says, what character does, what other character say about the character, and what others do (Barnet, S; Berman, M; \& Burto, William).

\section{a. The Character of Kino}

In general, Kino is prototypical of Mexican-Indian who works as a pearl diver, he begins the story as a devoted father and husband to his family. As the head of a family, Kino depends on nature, in this case ocean, for his family living. It is clearly shown in the following sentences. "It was at once property and source of food, for a man with a boat can guarantee a woman that she will eat something. It is the bulwark against starvation". (p.14) When the waters are rough, he cannot go diving. When the sun sets, his workday ends until the discovery of the pearl changes Kino's character.

Kino is an honest, dignified pearl diver who works hard to support his family. He is initially a simple and natural being who functions well in a traditional way of the village where he and his family lives in. He is conscious of his poverty and understands that money could buy things his family lacks. He hopes to find a pearl that will guarantee him a future peace. Like most human beings, he wants to get ahead.

Kino is the man who usually hears the 'song of the family'. It is the harmonious soothing message that all is well in life but after finding the pearl, he begins to hear the 'voice of suspicion', the sound of danger that is called 'the song of evil'. In the beginning, this song is really a powerful 
internal voice that Kino hears when dangers arise. It links him to his ancestors as a sort of built-in protection against death. It is Steinbeck's poetic way of referring to Kino's survival instinct.

\section{b. The Character of Juana}

The mother of Coyotito and the wife of Kino, Juana is the representation of woman for Steinbeck in the story. She is a good woman that submits to her husband. Juana supports her husband, even though she always warns him against the dangers that the pearl can bring to the family. In one occasion, Juana still keeps the pearl and gives it back to Kino right after Kino has just killed a man that tries to steal the pearl.

"They have taken the pearl. I have lost it. Now it is over," he said. "The pearl is gone." Juana quieted him as she would quiet a sick child. "Hush," she said. "Here is your pearl. I found it in the path. Can you hear me now? Here is your pearl. Can you understand? You have killed a man. (p.57)

Juana also has a strong survival instinct that her family is the major concerned. Once the doctor refused to treat Coyotito, Kino is disappointed and punches the gate. Juana, on the other hand, tries to save the baby by putting a seaweed poultice on the Coyotito's shoulder. Juana shows a direct action when she decides that the pearl is a threat to her family. She tries to pursue Kino to destroy the pearl before it destroys them. "Let us destroy it before it destroys us. Let us crush it between two stones. Let us throw it back in the sea where it belongs. Kino, it is evil, it is evil" (p.54)

Juana is also a religious and humble person. She always prays in a very great need and desire, since only God who will keep them survive. "And the canoe above him Kino knew that Juana was making the magic of prayer, her face set rigid and her muscles hard to force the luck, to tear the luck out of the God's hands, for she needed the luck for the swollen shoulder of Coyotito. And because the need was great and the desire was great, the little secret melody of the pearl that might be was stronger this morning. Whole phrases of it came clearly into the Song of the Undersea. (p.47)

\section{Feminism as Seen in Juana}

It is described in the story of The Pearl that Kino and Juana live in a patriarchal society. In the patriarchal society, especially in Mexico a man always takes the first step, and woman follows behind. It also happens in the story, that every time Kino has an idea, Juana will follow him. Kino stepped with dignity out of the house, and Juana followed him, carrying Coyotito. And as they marched up the freshet-washed alley towards the town, the neighbors joined them. (p.42) And Kino could hear the pad of Juana's feet behind him. He went quickly and quietly, and Juana trotted behind him to keep up. (p.65)

Juana's relationship to Kino, her husband, is made clear in the first chapter of The Pearl. She is a loving and devoted wife, the stabilizing force in Kino's life. At first, we may see her simply as subservient. But Juana has great inner strength and determination. For example, when the scorpion stings Coyotito, Juana acts immediately and sucks out the poison. She also insists that they see the doctor - an unheard-of event in the village.

"The doctor," she said. "Go to get the doctor." The word was passed out among the neighbors where they stood close-packed in the little yard behind the brush fence. And they repeated among themselves: "Juana wants the doctor." A wonderful thing, a memorable thing, to want the doctor. To get him would be a memorable thing. The doctor never came to the cluster of brush houses. Why should he, when he had more than he could do to take care of the rich people who lived in the stone and plaster house of the town? (p.07)

Juana remains steadfast throughout the story and devoted to follow Kino and maintaining her family. As a woman, she even refuses to obey Kino when he suggests that they take separate paths to avoid the trackers. "No", she said. "We go with you." (p.74)

When Coyotito was stung by a scorpion, Kino sees Juana as a patient and fragile wife but also strong and brave woman, even stronger than man. "Kino ha wondered often at the iron in his patient, fragile wife. She who was obedient and respectful and cheerful and patient, could bear physical pain with hardly cry. She could stand fatigue and hunger almost better than Kino himself. In the canoe she was like a strong man. And now she did a most surprising thing." (p.07) 
And Kino cannot deny that they have to go to the doctor as suggested by Juana. In this situation Kino follows Juana. She looked at him, her eyes as cold as the eyes of a lioness. This was Juana's first baby-this was nearly everything there was in Juana's world. And Kino saw her determination and the music of the family sounded in his head with a steely tone. The people in the door pushed against those behind to let her through. Kino followed her. They went out of the gate to the rutted path and the neighbors followed them. (pp.7-8)

There are many times of showing how Juana always struggle her belief that the pearl is an evil and it will bring disaster towards her family. However, Kino's will is so hard like a stone, Juana's words do not affect him to keep the pearl, especially every time Kino mentions the words, "I am a man".

He said: "I am a man," and that meant certain things to Juana. It meant he was half insane and half God. It meant that Kino would drive his strength against a mountain and plunge his strength against the sea. Juana, in her woman soul, knew that the mountain would stand while the man broke himself; that the sea would surge while the man drowned in it. And yet it was this thing that made him a man, half insane and half God, and Juana had need of a man; she could not live without a man. (p.56)

Juana sees a man as an immortal creature. After a trial on Kino's life Juana suddenly has a different perception about a man. "Kino," she said huskily, "I am afraid. A man can be killed. Let us throw the pearl back to the sea." (p.54)

There are many conflicts between Kino and Juana. The conflicts become worse because they have two different attitudes in solving a problem, Kino with his bravery and sometimes savage and Juana with her patience and strong belief. Kino extremely defends the pearl because he believes that it will bring happiness to his family. He is trapped by his ambition. The pearl has made him dream that Coyotito will be able to go to school, and he and Juana may be married in the church (p.20)

Unfortunately, some times he brings his brutality to defend his determination. Juana on the contrary, argues Kino to throw the pearl away with consideration that the pearl is dangerous and threatening their family. She feels a sign that the pearl will arise some dangerous situations to her family, after Kino has been attacked only one day after the pearl's finding. "This pearl is like a sin! It will destroy us," and her voice rose shrilly. "Throw it away Kino. Let us break it between two stones. Let us bury it and forget the place. Let us throw it back to the sea. It has brought evil. Kino, my husband, it will destroy us." (p.37)

Juana shows her strong reaction when Kino got the second attack from the anonymous enemy. Again, Juana persuades Kino to cast the pearl off unless all of them will die. Speaking strongly and crying, Juana falls in Kino's knees to save their family from the pearl's danger. "Kino, can you hear me?". "I hear you", he said dully. "Kino, this pearl is evil. Let us destroy it before it destroys us. Let us crush it between two stones. Let us throw it back to the sea where it belongs. "Kino it is evil, it is evil!"” (pp.53-54)

Even though Juana must involve in many conflicts with her husband, she still insists on her determination that the pearl is an evil, that Kino's dream is nonsense. So, she tries many times to catch it off to the sea, even though she ahs to face Kino's brutality.

He struck her in the face with his clenched fist and she fell among the boulders, and he kicked her in the side...Kino looked down at her and his teeth were bared. He hissed at her like a snake, and Juana stared at him with unfrighten-eyes, like a sheep before a butcher (p.55)

As a wife, Juana is quite faithful both in happiness and misery. She realizes her dangerous behavior, especially if she against Kino's decision. The first matter comes to her thought is Kino faces hard problem and she will not let him alone. In addition, Juana's strength is a leading spirit to Kino and actually he learns much from Juana.

He looked then for weaknesses in her face, for fear or irresolution, and there was none. Her eyes were very bright. He shrugged his shoulders helplessly then, but he had taken strength from her. When they moved on it was no longer panic flight (p.74) 
In contrast to the savage and Kino's brutality, Juana becomes stronger through the suffering she faces. Furthermore, it is Juana who remains awake at night, guarding Kino and Coyotito as Kino sleeps. Steinbeck juxtaposes Kino with Juana; while the man becomes more instinctual and animalistic; the woman retains her particularly, human qualities.

After they experience some hard challenges, they reach an agreement that they throw the pearl back to the sea. I think Kino has got unbelievable lessons for his life and then he respects Juana much more, because of her personality. When they come to their village, they are not walking in single file, Kino ahead and Juana behind, as usual, but side by side (p.84)

\section{Conclusion}

After analyzing the novel, the conclusion will be as follows; first, the study on The Pearl has shown that Juana represents woman's struggles in the family. Juana is a tough woman who can survive in the happiness and misery, even though she realizes that her behavior against Kino's decision causes danger to Coyotito. In addition, Juana's strength causes Kino has a spirit and actually he learns much from Juana.

Second, there is a contrast between Kino and Juana. In contrast to the savage and brutal Kino, Juana retains the human qualities. Juana becomes stronger through the suffering she faces. Furthermore, Juana remains awake at night, guarding Kino and Coyotito as Kino sleeps.

Third, Juana's feminism can be seen through her bravery to speak her idea about the pearl. Even though it is hard since she lives in a patriarchal society. As a consequence, Juana must involve in many conflicts with Kino. Juana still insists on her determination that the pearl is an evil, that Kino's dream is nonsense. So, she tries many times to catch it off to the sea, even though she has to face Kino's brutality.

Fourth, Juana's feminism has made the story of The Pearl becomes full of conflicts. Those conflicts between Kino and Juana actually draw emotion and imagination out of the readers. Through the conflicts along the story of The Pearl I get a description about the nature of the human being with all of personality they possess.

\section{References}

Omrany, Maryam and Pishkar, Kian. "Female Characters' Rule in Rise and Fall of Modern American Society: A Case Study of John Steinbeck's Masterpieces." Journal of Applied Linguistics and Language Research (2018): 109-117.

Hart, Jeni. "Women and Feminism in Higher Education Scholarship: An Analysis of Three Core Journals." The Journal of Higher Education (2006): 40-61.

Rorberger, Mary \& Wood, Samuel H Jr. Reading and Writing about Literature. New York: Random House, 1971.

Panhwar, Abdul Hameed \& Ansari, S. "Sociocultural Theory and its Role in the Development of Language Pedagogy." Advances in Language and Literary Studies (2016): 183-187.

Davis, Muray. Steinbeck: A Collection of Critical Essays. New York: Random House, 1972.

Murphy, M.J. Understanding Unseen: An Introduction to English Poetry and English Novel for Overseas Students. London: George Allen and Unwin Ltd., 1986.

Barnet, S; Berman, M; \& Burto, William. Literature for Composition. Boston: Scott, Foresman and Company, 1988. 